\title{
Redemption, Colonialism and International Criminal Law: The Nineteenth Century Slave- Trading Trials of Samo and Peters
}

\author{
Emily Haslam
}

\begin{abstract}
You are the first convicted under this act, and England will anxiously look for such an example to be made, as will infuse terror and dismay into the minds of every remaining slave factor on these coasts. ${ }^{1}$

My Lord, and Gentlemen of the Jury, reflect for a moment on the miseries of slavery, what is it that the poor African does not endure? Think of the separation of husband and wife, father and mother, children, brothers, sisters, kindred, and friends; think of the cold, the heat, the labour and the lash, that unfeeling custom has doomed to the condition of the slave; and to whom shall he apply for redress? I glory in knowing that he can apply to British law ...2
\end{abstract}

\section{Introduction}

In April 1812 in the Vice Admiralty Court of Sierra Leone, Chief Justice Robert Thorpe dramatically convicted and then pardoned Samuel Samo for slavetrading. The courtroom was crowded and the atmosphere was highly charged. The attorney-general, James Biggs, opened the prosecution with the expansive claim that the case 'embraces the essential concerns of one quarter of the globe we inhabit, and involves the security and morals, the happiness and liberty, of millions yet to live'. ${ }^{3}$ In announcing Samo's pardon, Thorpe proclaimed, 'You have received the mercy of the royal pardon - May your future conduct deserve that of our Father who is in heaven'. ${ }^{4}$ After this homily, Samo is said to have withdrawn in a 'death like silence' whilst others wept in the courtroom. ${ }^{5}$

\footnotetext{
1 Robert Thorpe CJ in The Trials of the Slave Traders, Samuel Samo, Joseph Peters and William Tufft Before the Hon. Robert Thorpe, L.L.D. with Two Letters on the Slave Trade From a Gentleman Resident at Sierra Leone to an Advocate for the Abolition in London (The Trials of the Slave Traders) (London: Sherwood, Neeley, and Jones, 1813) 33, Anti-Slavery Recovered Histories at http://www.recoveredhistories.org/pamphletl. php?catid=50 last accessed 17 October 2011.

2 Mr Biggs, in The Trials of the Slave Traders, 27.

3 ibid., 13.

4 Thorpe, in The Trials of the Slave Traders, 39.

5 ibid.
} 
At the time, Samo's case attracted widespread interest and generated political controversy and debate beyond the colony. And yet, this case and the subsequent trials of Charles Hickson, Joseph Peters, William Tufft and Thomas Wheeler, have been overlooked in accounts of the development of international criminal law. As the first tranche of proceedings brought under the British Slave Trade Felony Act 1811, which made slave-trading a felony, ${ }^{6}$ they represent a handful of the criminal and civil law cases from the early nineteenth century dealing with the slave trade and abolition. These have been largely overlooked by international legal scholars. Whilst it is true that there is a significant body of literature related to the United States, ${ }^{7}$ the literature dealing with the English context has tended to focus on a few key cases, ${ }^{8}$ to emphasise the activities of a narrow group of abolitionists, ${ }^{9}$ and to overlook (international) criminal law. ${ }^{10}$ Present-day approaches overwhelmingly trace the origins of contemporary international criminal law to the Nuremberg and Tokyo Trials. ${ }^{11}$ The neglect of this earlier litigation is disappointing. ${ }^{12}$ Slave-trading was one of the first international crimes. ${ }^{13}$ Legal and institutional responses to the slave trade gave rise to many similar controversies that face the international community today, including the limits of international intervention and the extent of criminal responsibility. This chapter begins the process of exploring what international criminal law looks like when slavery litigation is brought back into the picture by examining some of the early slave-trading trials before the Vice Admiralty Court of Sierra Leone. In particular the focus is on

6 An Act for Rendering More Effectual an Act made in the Forty Seventh Year of His Majesty's Reign, entitled An Act for the Abolition of the Slave Trade, 51 Geo III C 23, 14 May 1811 (Slave Trade Felony Act).

7 For example, Robert Cover, Justice Accused: Antislavery and the Judicial Process (New Haven: Yale University Press, 1975).

8 Most notably Somerset v Stewart (1772) 98 Eng. Rep. 499; Gregson v. Gilbert 99 Engl. Rep 629 and The Slave, Grace, (1827) 166 Eng. Rep. 179. See further, F.O. Shyllon, Black Slaves in Britain (London: Oxford University Press, 1974).

9 For example, William Wiecek, 'Somerset: Lord Mansfield and the Legitimacy of Slavery in the AngloAmerican World', University of Chicago Law Review 42, (1974-75): 86; Steven Wise, Though the Heavens May Fall (Cambridge, MA: Da Capo Press, 2005).

10 To the extent that literature deals with international law, it tends to focus on the struggles over search and seizure in relation to slave ships, see Leslie Bethell, 'The Mixed Commissions for the Suppression of the Transatlantic Slave Trade in the Nineteenth Century', Journal of African History VII, 1 (1966): 79-93; Holger Lutz Kern, 'Strategies of Legal Change: Great Britain, International Law, and the Abolition of the Transatlantic Slave Trade', Journal of the History of International Law 6, (2004): 233-58; Howard Hazen Wilson, 'Some Principal Aspects of British Efforts to Crush the African Slave Trade, 1807-1929', The American Journal of International Law 44 (1950): 505-26.

11 See, for example, Antonio Cassese, 'From Nuremberg to Rome: International Military Tribunals to the International Criminal Court', in The Rome Statute of the International Criminal Court: A Commentary, vol. I, eds, Antonio Cassese, Paola Gaeta and John R.W.D. Jones (Oxford University Press, 2002): 3-19; Madoka Fatumura, War Crimes Tribunals and Transitional Justice: The Tokyo Trial and the Nuremberg Legacy (Abingdon: Routledge, 2008); Dominic McGoldrick, 'Criminal Trials before International Tribunals: Legality and Legitimacy', in The Permanent International Criminal Court: Legal and Policy Issues, eds, Dominic McGoldrick, Peter Rowe and Eric Donnelly (Oxford: Hart, 2004): 9-46.

12 And, perhaps inevitable given 'the singular focus on Nazi war criminals' as 'the exemplification of evil', Gerry Simpson, 'Didactic and Dissident Histories in War Crimes Trials', Albany Law Review 60 (1996-97): 811. 13 Piracy is widely considered to be the first international crime, Gerry Simpson, Law, War and Crime (Cambridge: Polity Press, 2007) 161-62. 
two of the trials, that of Samo and, to a lesser extent as a point of comparison, that of Peters. This contribution focuses less upon the doctrinal significance that this body of litigation had in the development of international criminal law. Rather, its focus is on the didacticism that emanated from the courtroom in Samo's case and its similarities to that occurring in contemporary international criminal trials. It argues that, in Samo's case, a religiously accented adjudicative logic of redemption was deployed in the service of a broader colonial project. The chapter suggests that this redemptive framework continues to exert influence in contemporary international criminal law. Today, these narratives are for the most part secularised with transition to democracy and the rule of law replacing emancipation and reconciliation replacing redemption. By suggesting the deployment of this narrative for a colonial project, this chapter seeks to contribute to a richer history of the development of international criminal law and more specifically its redemptive trope. ${ }^{14}$

The chapter begins by setting out the legal, institutional and political context of these cases by exploring the Slave Trade Felony Act 1811 and the significance of Sierra Leone to abolitionists at institutional and symbolic levels. Whilst the cases examined here are essentially 'British' rather than 'international', they are relevant to international criminal law because of the leading role that Britain played in developing strategies and tools to abolish the slave trade at the international level, ${ }^{15}$ and because participants in the Vice-Admiralty hearings engaged with thorny international legal questions of jurisdiction and nationality. Whilst the aim of the chapter is to contribute to a more expansive account of the development of international criminal law, it does not intend by focusing on British cases, to gloss over other, particularly non-European, contributions to the development of international criminal law. ${ }^{16}$ The third section explores the cases before moving on to examine the contestation to which they gave rise. Such contestation demonstrates that abolitionists understood law's potential to contribute to the construction of public memory and the importance of the trial as a show. ${ }^{17}$ This final section explores the logic of redemption that ran through

14 For criticisms of this redemptive trope see, for example, Thomas Brudholm, Resentment's Virtue: Jean Amery and the Refusal to Forgive (Philadelphia: Temple University Press, 2008).

15 See, for example, Suzanne Miers, Britain and the Ending of the Slave Trade(London: Longman 1975); Ethan Nadelmann, 'Global Prohibition Regimes: The Evolution of Norms in International Society', International Organisation 44, (1990): 479-526.

16 For the criticism that non-Eurocentric origins are all too often overlooked in international legal histories see, for example, Upendra Baxi, The Future of Human Rights (Oxford University Press, 2002); Balakrishnan Rajagopal, International Law from Below: Development, Social Movements and Third World Resistance (Cambridge University Press, 2003).

17 For an excellent account of the construction of memories of abolition (which however does not deal with law and litigation) see J.R. Oldfield, 'Chords of Freedom': Commemoration, Ritual and British Transatlantic Slavery (Manchester University Press, 2007). On remembering the slave trade and abolition see further, Catherine Hall, 'Remembering 1807: Histories of the Slave Trade, Slavery and Abolition', History Workshop Journal 64, (2007): 1-5; Elizabeth Kowaleski Wallace, The British Slave Trade and Public Memory (Chichester: Columbia University Press, 2006). 
Samo's case and the political usage made of it. The chapter concludes by positing Samo's case as evidence of how the redemptive trope of international criminal law has been implicated in a colonial project.

\section{Background to the cases}

Shortly after Britain abolished the slave trade in $1807,{ }^{18}$ it became apparent that the penalties provided by the Abolition Act were insufficient. ${ }^{19}$ The potential profits that slave-trading could generate made the financial penalties far too derisory to deter the practice. On 14 May 1811, the Slave Trade Felony Act was passed, instigated within parliament by Henry Brougham, Member of Parliament for Camelford. By section 1, removal, or assisting in the removal, transportation and shipment of slaves by British subjects, or in British territory, became a felony; and the legislation also provided increased penalties of imprisonment and hard labour for between three and five years or transportation for 14 years, thereby degrading slave factors, in the words of Thorpe CJ, to 'pickpockets and swindlers' ${ }^{20}$

In terms of the numbers of prosecutions, the impact of the Act was negligible. ${ }^{21}$ This may explain the lack of attention that has been paid to the cases by (international) legal scholars. Nonetheless, this does not mean that the Act's significance should be underestimated in assessing how it helps further our understanding of the development of international criminal law. The limited numbers prosecuted (whilst revealing) should not be allowed to obscure the messages participants attempted to deliver through litigation and how these prosecutions were 'read' at the time, both inside and outside the courtroom.

18 An Act for the Abolition of the Slave Trade 47 Geo. III c 3, 25 March 1807 (Abolition Act). On abolitionism more generally see further, Roger Anstey, The Atlantic Slave Trade and British Abolition 1760-1810 (London and Basingstoke: Macmillan, 1975); Robin Blackburn, The Overthrow of Colonial Slavery, 1776-1748 (London and New York: Verso, 1996); Adam Hochschild, Bury the Chains: The British Struggle to Abolish Slavery (Basingstoke and Oxford: Macmillan, 2005).

19 See, for example, Mr Brougham, House of Commons Debate, 5 March 1811, vol. 19, cc 233-40. See further Monroe H. Freedman, 'Henry Lord Brougham - Advocating at the Edge for Human Rights', Hofstra Law Review 36 (2007): 311-22.

20 The Trials of the Slave Traders, 11.

21 Marika Sherwood, After Abolition: Britain and the Slave Trade since 1807 (London: I.B. Tauris, 2007), 301. See further, Old Bailey Proceedings Online (http://www.oldbaileyonline.org) February 1817, Trial of John Bean Hannay (t18170219-123); Old Bailey Proceedings Online (http://www.oldbaileyonline.org), February 1819, Trial of Philippe Caday, alias Phillibert Armand Clerensac, Joseph Ann Tresgrose (t18190217-36); Old Bailey Proceedings Online (http://www.oldbaileyonline.org), January 1820, Trial of Jaques Alexandre Carrol, Alexandre Villemont (t18200112-66). See further, Proceedings under the Slave Trade Felony Act in the Island of Ceylon, Admiralty Commission of Oyer and Terminer, May 171813 and Proceedings under the Slave Trade Felony Act in the Island of Java, 2 October 1813, reported in Ninth Report of the Directors of the African Institution, 12 April 1815 (London: Ellerton and Henderson, 1815) (Google books last accessed 10 November 2011). 
Sierra Leone was an institutionally prominent site in slave trade abolition, the 'centre of the government's efforts to suppress the wider trade'. ${ }^{22}$ As home, first to Vice Admiralty and then to mixed commission courts at Freetown, Sierra Leone was the location in which much early jurisprudence relating to abolition was decided. Beyond that, it played a central symbolic role for abolitionists. Wellknown British abolitionists had played a pivotal part in each of the attempts to establish Sierra Leone as a colony, including in 1787, 1790, and then, finally, in 1808 when it became a Crown Colony. Its origins can be traced from Granville Sharp's plan to establish a home for poor black Londoners to those abolitionists who invested in the Sierra Leone Company. Many of these became influential in the African Institution, which was established after abolition with the professed objective of promoting civilisation and happiness in Africa. ${ }^{23}$

Sierra Leone was beset with a series of problems, including the controversial practice of enlisting and apprenticing former slaves. ${ }^{24}$ Partly as a result of raising these concerns the previous governor, Thomas Thompson, was replaced in 1810 by Edward Columbine. This was the volatile political context in which Thorpe was appointed Chief Justice of Sierra Leone in 1808, although he was not allowed to travel to Sierra Leone until 1811. Thorpe was no stranger to controversy, having previously been removed as a judge in Upper Canada. ${ }^{25}$ Thorpe's criticisms of the management of Sierra Leone drew him into a bitter conflict with the African Institution. He was relieved of his post in 1815, for reasons which included the complaints that he made against that institution, some of which featured in the pamphlet debate over Samo's pardon. ${ }^{26}$

\section{The trials of Samo, Peters, Tufft, Wheeler and Hickson}

The trials of Samo, Peters, Tufft, Wheeler and Hickson took place between April and June 1812. A detailed account of the trials was written by a 'gentleman resident at Sierra Leone to an advocate for the abolition in London'. These reports were made public, with the view of affording:

\footnotetext{
22 David Lambert, 'Sierra Leone and Other Sites in the War of Representation over Slavery', History Workshop Journal 64, (2007): 105.

23 ibid., 105.

24 Section 7 of the Abolition Act permitted 'slaves taken as prizes or forfeitures' to be 'enlisted for the land or sea-service' or 'bound as apprentices, whether of full age or not, for a term of 14 years'. Section 17 provided for the renewal of such apprentices at the end of their term.

25 John McLaren, "“Men of Principle or Judicial Ratbags? The Trials and Tribulations of Maverick Colonial Judges in the 19th Century" or "A Funny Way to Run An Empire"', Windsor Review of Legal \& Social Issues 27 (2009): 150.

26 ibid., 149-50.
} 
the British Legislature, the Government, and the people in general, an early and correct view of the operation of the recent slave felony act of parliament: an act which reflects the highest honour on those whose humanity was so determined and conspicuous in conducting to a happy issue the long and strenuously contested question of African emancipation. ${ }^{27}$

The pamphlet is not an official account. The identity of the author is not declared. Yet, in the debates that followed Samo's pardon, the African Institution suggested that it was published either by Thorpe or by his friends. ${ }^{28}$ In the absence of an official report, this document is the source from which the following account of the trials of Samo and Peters is drawn. The account was clearly influenced by the pamphlet writer's broader objectives as noted above. Even so, the way in which he told the story of the trials, even if not a verbatim record, is revealing. Assuming the African Institution was correct that Thorpe approved of publication, the account can be seen as strong evidence of how the judge framed the role of law in abolition.

Samo was indicted for five counts of slave-trading between August 1811 and January 1812. Samo's twofold plea in response to the substantive offences appeared to be that he was respectable, an assessment supported by a number of witnesses, and that he had been working towards abolition. ${ }^{29}$ Samo was found guilty. However, Samo had also raised a more fundamental procedural objection to the jurisdiction of the court, which he renewed at the sentencing stage. He maintained that the Slave Trade Felony Act 1811 only applied to British subjects. Further he argued that as he was Dutch and, moreover, residing outside British jurisdiction in the Rio Pongas (now Guinea), the Act did not apply to him. Thorpe rejected these legal objections with the observation that the chiefs of the Rio Pongas treated white men living there as British. ${ }^{30}$ Although dismissed at this stage, these jurisdictional objections return to centre stage in the debates that followed.

When it came to sentencing, as Thorpe observed, there was not any obvious mitigating evidence on Samo's behalf. Nor was this a case where the jury had recommended his sentence to be reduced. ${ }^{31}$ Despite this, he deferred sentencing Samo 'in the hope of finding such exertions made by your friends to extirpate this trade, as will in a great measure diminish, though they may not be able to

\footnotetext{
27 The Trials of the Slave Traders, v.

28 Special Report of the Directors of the African Institution Made at the Annual General Meeting on the 12 of April 1815 Respecting the Allegations Contained in A Pamphlet Entitled 'A Letter to William Wilberforce' (African Institution, Special Report), (London: Ellerton and Henderson, 1815), 93 (Google books last accessed 11 November 2011).

29 The Trials of the Slave Traders, 21-22.

30 ibid., 31.

31 ibid., 33.
} 
eradicate it' $^{32}$ In this way the judge opened his determination of sentence to external influences, making a pardon conditional on the willingness of others to show penitence by renouncing the slave trade. He continued:

And in proportion to the contrition exhibited, and the zeal for its destruction manifested, the discretion which the law gives to the Court shall be extended to you; and if it appears evidently the intention of the other slave factors, in the vicinity of this colony, to lead a new life, and turn benevolent and industrious, I will use my influence with the amiable personage at the head of this Government to extend the royal mercy to you on this laudable salutary and necessary repentance. ${ }^{33}$

The Chief Justice's call seems to have received favourable answers. As a result of the respect in which Samo was apparently held, the court received several petitions from such eminent persons as the king of Mandingo and the king at Isles de Loss. Petitioners promised to renounce the trade if Samo were granted a pardon. ${ }^{34}$ Thorpe claimed, 'it is not the individual victim of the law that is the most valuable' but 'the annihilation of the diabolical traffic is the victim the law demands', ${ }^{35}$ and this was an action of which the gentleman letter writer thoroughly approved. ${ }^{36}$

Other defendants fared better. Days after Samo's trial ended, Charles Hickson was tried for the same offence and acquitted. A short while later, Thomas Wheeler, the acting agent at Bance Island, was also acquitted - the principal witness having returned home for fear of offending neighbouring kings. ${ }^{37}$ Some defendants, however, met with less lenient treatment. William Tufft, a black, English-educated, former servant, essentially pleaded that he was acting under the orders of others, which was not accepted on the evidence. He was sentenced to three years hard labour on public works at Sierra Leone, but his sentence was commuted on condition that he join the Marine Corps for life. Tufft's associate, Joseph Peters, who was tried in June 1812, found the court in a particularly unforgiving mood. His conduct, Biggs said, was compounded by ungratefulness, because he was in receipt of British pay 'for attendance on British troops' ${ }^{38}$ Central to Peters's case was a narrative of both resistance and complicity. Peters had rewarded Chief Dallamoodoo and King Murra Brimer with slaves because they had helped him secure the recapture of fugitive slaves. Peters's trial is also

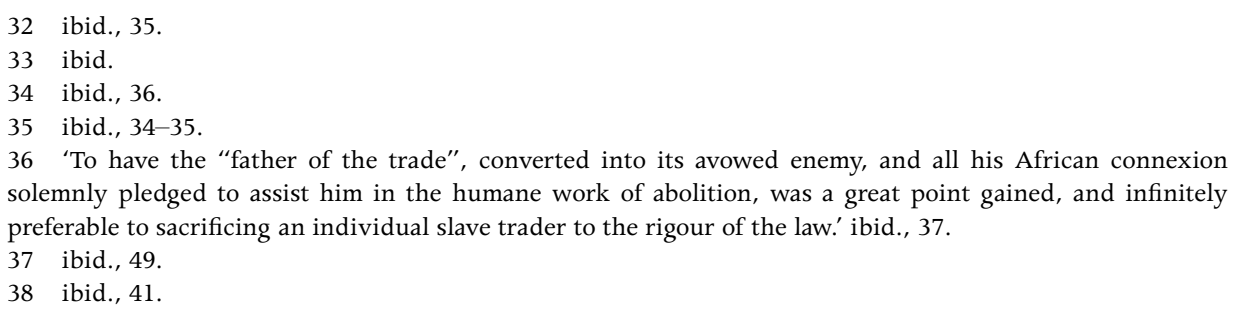


notable for the part played by Africans in testifying against him. ${ }^{39}$ Peters was sentenced to seven years transportation. He remained in prison until he was pardoned by the governor on the condition that he left Africa for ever. ${ }^{40}$

\section{Samo's case contested}

Samo's case became a point of bitter contestation amongst prominent abolitionists. This debate formed part of a broader pamphlet dispute in which Thorpe made a series of damaging accusations about the Sierra Leone Company and the African Institution in a public letter to William Wilberforce, ${ }^{41}$ some of which resonated with those made earlier by Governor Thompson. ${ }^{42}$ Whilst Samo's case was not the primary focus of this contestation, concerns that Thorpe raised about the allegedly oppressive exercise of jurisdiction against slave-traders by the authorities in Sierra Leone brought his own treatment of Samo into the frame.

For, amongst the many criticisms he levelled, Thorpe railed against the treatment of individuals apprehended outside the jurisdiction of Sierra Leone and convicted of slave-trading, in a manner that he considered to be both illegal and heavy-handed. In one such extra-territorial expedition in June 1813, HMS Thais arrested Robert Bostwick and John M'Queen, destroyed their factory and released over 240 slaves to Sierra Leone and condemned them as slavers. ${ }^{43}$ Bostwick and M'Queen were sentenced to 14 years transportation but were freed following a successful petition to the Prince Regent. Other extra-territorial expeditions organised by Lieut-Colonel C. W. Maxwell who had been appointed Governor in July 1811, came under Thorpe's fire. Thorpe criticised the resulting sentencing in his absence by his non-lawyer deputy, Robert Purdie, of Malcolm Brodie, George Cooke and James Dunbar to transportation for slave trading and of Charles Hickson to hard labour on public works. Thorpe's concerns about jurisdiction were justified in so far as Brodie, Cooke and Dunbar were pardoned

\footnotetext{
39 He appears to have been convicted almost solely on the testimony of Africans, including former slaves. The evidence of at least 14 Africans (Banta, Dallamoodoo, Tom Krooman, Duboo, Yangyaraa, Adam, Bondoo, Quiepa, Saree, Borega and Boree) including three women (Monday, Foosingbag, Katta) is reported, in addition to that of Kenneth Macaulay 'Esq'. The court's treatment of African testimony of complicity and resistance in this case is explored in a further article in draft with the author.

40 Report of the Committee of the African Institution, vol. 8 (London: Ellerton and Henderson, 1814), 15 (Google books last accessed 11 November 2011).

41 Robert Thorpe, A Letter to William Wilberforce, ESQ. M.P. Vice President of the African Institution Containing Remarks on the Reports of the Sierra Leone Company, and African Institution with Hints Respecting the Means by Which An Universal Abolition of the Slave Trade Might Be Carried into Effect (Letter to William Wilberforce) (London: Law and Gilbert, 1815) Anti-Slavery Recovered Histories at http://www. recoveredhistories.org/ last accessed 11 November 2011.

42 Including the enlistment and apprenticeship of freed slaves, a practice Thorpe compared to slave-trading, 'involuntary servitude for life, established by an Act of Parliament, purporting to abolish slavery'. ibid., 46. 43 ibid., 19.
} 
as a result of being tried in the wrong court. ${ }^{44}$ However, his criticism of his deputy, Purdie, forced him to justify his own conduct in Samo's case because Samo had also been apprehended outside the jurisdiction of Sierra Leone. ${ }^{45}$ Thorpe explained:

to my great surprise and annoyance, Samuel Samo, and Charles Hickson were brought before me, as British subjects trading in slaves; they were seized by Governor Maxwell's orders at the Isles de Loss, for selling slaves in the Rio Pongas, neither of which places were ever considered as belonging to Great Britain, nor did British jurisdiction ever extend over them in any shape ... I found, however, so many insurmountable difficulties (for I was bound to protect the legal rights of the prisoner), that I informed the Governor, that I could not pronounce the sentence directed by the Act on Samo; and to prevent my reasons from being publickly known (lest they might affect the Abolition cause,) I advised the Governor to send to the Rio Pongus [sic], induce the Chiefs to ask for Samo's pardon, and influence them to promise, that if their petition was granted, they would allow no more Slave trading in their dominions. ${ }^{46}$

In this way Thorpe challenged the idea that it was his actions in Samo's case that constituted a precedent for Purdie in the cases of Brodie, Cooke and Dunbar. He claimed, 'I rebuked the outrage, and refused to adjudge any punishment, having declared to the Governor, I was not authorised to do so' ${ }^{47}$

In revealing that he suggested the pardon because his court did not have jurisdiction in the case, Thorpe displayed both a concern for adherence to the law coupled with an understanding of the potential for its strategic deployment. Thus, he appears to have understood the value of clothing his potentially unpalatable verdict in the international legal idea of jurisdiction, even when earlier in the trial he had rebuffed Samo's challenge to the court's jurisdictional competence. This understanding of the importance of law was also reflected in broader debate, showing how protagonists understood the contribution

\footnotetext{
44 According to the opinion of the Crown Office lawyers. They could only have been tried in the colonial court of Sierra Leone had a special commission been issued to permit such a trial. To the African Institution's charge that Thorpe was primarily responsible for obtaining such a commission, Thorpe responded that he had been unaware of the impending extra-territorial actions planned by the governor. African Institution, Special Report, 96; Robert Thorpe, Postscript to the Reply 'Point by Point' Containing an Exposure of the Misrepresentation of the Treatment of the Captured Negroes at Sierra Leone and Other Matters Arising From the Ninth Report of the African Institution (London: R. \& R. Gilbert, 1815) (Google books last accessed 10 November 2011), 44 (discussing the actions against Samo and Hickson). In fact Cooke was awarded damages of $£ 20,000$ in an action against Maxwell before the King's Bench in 1817, which the government assumed responsibility for paying. Brodie died although he also instituted proceedings and Bostock agreed an out of court settlement, see Christopher Fyfe, A History of Sierra Leone (Oxford University Press, 1962) 123.

45 See further, African Institution, Special Report, 98.

46 Letter to William Wilberforce, 18-19.

47 Robert Thorpe, Postscript, 38.
} 
law could make to the public memory. For example, the African Institution claimed that it was vital that the 'proper' interpretation should be placed on the pardon, a position echoed by William Wilberforce. Wilberforce's concern, as expressed in the House of Commons debate following his unsuccessful motion to institute an inquiry on Brodie, Cook and Dunbar, was that 'considerable error had crept into the world' because people believed that their pardon was granted on the merits rather than on a legal technicality. ${ }^{48}$ These struggles show how abolitionists appreciated the capacity of the law to contribute to collective memory and the importance of the didactic potential of the law. This can be seen from the lengths Thorpe went to inside the courtroom to create a show of pardoning Samo, notwithstanding his concerns about lack of jurisdiction and notwithstanding that his verdict apparently rested on the basis of a negotiated compromise. It is to this show that this contribution now turns.

\section{The logic of redemption and international criminal law}

Samo's trial was a spectacle, in which a religiously inflected logic of redemption at the individual and collective levels was used to legitimise a colonial project, ${ }^{49}$ central to which was the idea of Britain as an abolitionist state. ${ }^{50}$ This logic was manifested in an implicit and sometimes explicit discourse of sin and redemption at the individual and collective levels. ${ }^{51}$ Stories of individual redemption and its relationship to the collective were played out in the context of witnesses, the defendant and a broader community. These stories served a wider political project and were deployed to exculpate as much as to implicate. This logic continues to resonate in contemporary international criminal law,

\footnotetext{
48 British Parliamentary Debates (Hansard), House of Commons Debates, vol. 30, 14 April 1815. In the debate that followed regarding the establishment of a parliamentary inquiry, concern was expressed 'when they recollected all that was necessary for furthering the great work of abolition, it could not be unimportant to have all the aspersions and calumnies which had been cast upon the Government removed; and to show that it had not taken any part against the abolitionists, but that the sentence had been remitted through a mere defect of form in the trial', Mr Whitbread, Hansard, vol. 30, 14 April 1815.

49 Thorpe CJ made frequent references to the divine, for example, 'crime against God or man', The Trial of the Slave Traders, 34. These references to religion are matched outside the courtroom by the judge's view of the law of nations. Thorpe claimed that the 'law of nations is built on the unerring rules of justice, which unchangeably direct every law, human or Divine, for individual man, or collective empire; it is founded on the law of nature, directed by the law of God' (Thorpe, A Letter to William Wilberforce, 61).

50 On the well documented 'moral pressure' that abolitionists lent to the imperial project see David Rieff, $A$ Bed for the Night: Humanitarianism in Crisis (London: Vintage, 2002), 59; Miers.

51 On the role of religion in abolitionism, see Christine Bolt and Seymour Drescher, Anti Slavery, Religion and Reform (Kent: William Dawson and Sons, 1980); Huw T. David, 'Transnational Advocacy in the Eighteenth Century: Transatlantic Activism and the Anti-Slavery Movement', Global Networks 7, 3 (2007): 367-82; David Turley, The Culture of English Antislavery, 1780-1860 (London and New York: Routledge, 1991).
} 
albeit in a secularised version. It is hoped that tracing this logic of redemption and its usage will contribute to a richer account of the history and politics of international criminal law.

Biggs - and the pamphlet writer - saw the trial as a fundamental step to emancipation. However, in Samo's case, this transition did not necessarily require the conviction and punishment of the accused. If conviction and punishment were not central to transition, pardon and redemption were. The courtroom provided a space in which the sin, pardon and redemption of the accused and others could be theatrically performed. Thus, whilst Samo was ostensibly central to proceedings, his case was used to create a show of publicly exonerating and blaming others.

Witnesses did not only testify for the purposes of giving evidence but, by participating in the trial, they were able to redeem themselves, even if their redemption was achieved after a personal struggle. Take Samo's clerk, William Skelton, who on Biggs's persuasion became convinced of the 'exceeding wickedness and cruelty of the slave trade' to testify against his former master. Biggs compared his conduct favourably with that of other named slave-traders who refused to 'renounce the monstrous traffic' ${ }^{52}$ Biggs lamented the death of one of the principal witnesses by noting his remorseful atonement:

Mr David James Lawrence fell a victim to disease and a broken heart, in consequence of the vile treatment and persecution of the slave traders, who hated him because he had renounced their fellowship and business, and complied with the laws of his country. ${ }^{53}$

In the pamphlet debate, Thorpe was particularly critical of the conviction of Brodie, who had testified in Samo's case, promising to renounce the slave trade. $^{54}$ Thorpe saw no evidence that Brodie had broken this promise. ${ }^{55}$ This redemptive framing found its apogee in the pardon that was granted to Samo. Thorpe proclaimed:

let that baneful commerce which has so long retarded the civilization, diminished the population, and dimmed the glory of Africa, be destroyed - let it be shattered to atoms in a storm of benevolent charity for mankind — it will be an immolation acceptable to the Deity — it will

\footnotetext{
52 The Trials of the Slave Traders, 24.

53 ibid., 24-25.

54 Robert Thorpe, Postscript, 36-37.

55 Although the testimony, as reported was hardly expansive, 'he does not know of Mr Samo supplying any slaves; the slave dealers trade as secretly as possible, to evade the acts' (The Trials of the Slave Traders, 18).
} 
be a sacrifice of human viciousness on the altar of Divine compassion it will be death until sin - and a new birth unto righteousness - it will plead your pardon in this life, and plead for mercy in life everlasting. ${ }^{56}$

This redemptive logic lent support to the idea of Britain as an abolitionist state and was deployed to buttress a colonial imperative. First, take the reporting of the case. In accordance with the logic of what Makau Mutua has described as a 'savage-victim-savior' metaphor in human rights law, ${ }^{57}$ the pamphlet writer's aim was to inform of the 'beneficial effects arising from their disinterested zeal in behalf of those thousands of enslaved Africans who could do nothing for themselves'.$^{58}$ Further, driven as it may have been by his concerns about legal jurisdiction, the pardon gave Thorpe an opportunity to exercise leverage over powerful individuals outside the court's jurisdiction. In this way redemption in the form of pardon could be mobilised to buttress other imperial ambitions. Thorpe saw Samo's case as providing an opportunity to extend Britain's territorial rights on the coast. ${ }^{59}$ Writing to Governor Maxwell about Attorney General Biggs, Thorpe wrote:

I am convinced you are too deeply indebted to him by his extricating you from a most severe difficulty; the friends of the Abolition are too deeply indebted to him for his exertions in the slave trade; and Great Britain is too deeply indebted to him for the extra territorial he has established on the coast for her. ${ }^{60}$

Third, the hearings made a show of absolving the British public and the British state from guilt. As is widely observed, international criminal hearings make partial histories, despite their avowed archival functions. Not only is the production of history constrained by the demands of the legal process ${ }^{61}$ but,

56 ibid., 35 .

57 'The human rights corpus is driven — normatively and descriptively — by ... the savage-victimsavior metaphor, in which human rights is a grand narrative of an epochal contest that pits savages against victims and saviors. In this script of human rights, democracy and western liberalism are internationalized to redeem savage non-Western cultures from themselves, and to alleviate the suffering of victims, who are generally non-western and non-European' (Makau Mutua, 'Terrorism and Human Rights: Power, Culture, and Subordination', Buffalo Human Rights Law Review 8 (2002): 5).

58 The Trials of the Slave Traders, v.

59 On the deployment of humanitarian concerns in the interests of empire in a contemporary context see, for example, Amy Bartholemew, ed., Empire's Law: The American Imperial Project and the 'War to Remake the World' (London: Pluto Press, 2006); Costas Douzinas, Human Rights and Empire: The Political Philosophy of Cosmopolitanism (Abingdon: Routledge-Cavendish, 2007).

60 As quoted in the African Institution, Special Report, 103.

61 Marie-Bénédicte Dembour and Emily Haslam, 'Silencing Hearings? Victim-Witnesses at the ICTY', European Journal of International Law 15, no. 1 (2004): 151-77. 
as Gerry Simpson argues, all too often those histories are consciously deployed as part of a broader legitimising, ${ }^{62}$ or state building function. ${ }^{63}$ Of the British public, Thorpe observed in Samo's case:

Could the animated skeletons that are landed here, imploring death for relief, be visible in England, an universal exclamation would involuntarily burst from that inestimable people — 'Without ocular demonstration, we could not have believed that human depravity could have extended to these enormities - extirpate these monsters!' 64

As regards the British state, Biggs in opening Samo's prosecution observed:

the humane and anxious desire of the Parliament of the British empire to abolish the barbarous traffic in slaves is universally known, the remotest tribe on the face of the earth are apprized long ere this of the benevolent desire of every good mind in England, that however savage might be the race of distant climes, their land should not contain a single slave. ${ }^{65}$

Biggs portrayed Britain's support of the slave trade as provisional and reluctant:

through the unwise and tyrannical system of Dutch, Portuguese, Danish, Spanish and French colonization, England was obliged unwillingly to acquiesce in the temporary policy of an iniquitous slave trade, yet she never for a moment lost sight of the grand and ultimate determination of effecting its radical and signal prostration. ${ }^{66}$

The individualising of the slave-traders' guilt also operated to disassociate them from their national state, notwithstanding the role that Britain had played in the slave trade more generally. ${ }^{67}$ Thus, Biggs maintained that Peters was daily violating the Slave Trade Felony Act and 'acting with practical ingratitude

62 For example, the Nuremberg and Tokyo trials can be seen as 'attempts to vindicate the superiority of Western civilisation and the conduct of the Allied war'; Gerry Simpson, 'Didactic and Dissident Histories', 830 .

63 ibid., 827. Notably, the Eichmann trial was at least partly about the legitimacy of the establishment of the state of Israel (ibid., 826). So too is it argued that a driving force behind the establishment of the International Criminal Tribunal for the former Yugoslavia was the need for the West to affirm its 'own fundamental morality' (Pierre Hazan, Justice in a Time of War: The True Story behind the International Criminal Tribunal for the Former Yugoslavia (Texas: A \& M University Press, 2004), 19).

64 The Trials of the Slave Traders, 11.

65 ibid., 14.

66 ibid.

67 See, for example, David Brion Davis, The Problem of Slavery in the Age of Revolution 1770-1823 (Ithaca and London: Cornell University Press, 1975); Kenneth Morgan, Slavery and the British Empire From African to America (Oxford University Press, 2007); Hugh Thomas, The Slave Trade: The History of the Atlantic Slave Trade 1440-1870 (London and Basingstoke: Picador, 1997); James Walvin, Black Ivory: A History of British Slavery (London: Harper Collins, 1992). On British involvement in the slave trade after abolition, see Sherwood. On the 'fiction of detachability' in international criminal law according to which 'the state ... is imagined as an entity distinct from its bad apples and rogue statesmen' see Gerry Simpson, Law, War and Crime, 63. 
towards the country from which he derived his subsistence' ${ }^{68}$ At the same time, redemption provided an opportunity for British slave-traders to reconcile with abolitionism; compare Biggs's elaborate description of the 'redemption' of Skelton and Lawrence to the absence of the themes of pardon, sin and redemption in Peters's case, notwithstanding the centrality to that case of the resistance of runaway slaves and the complicity of those recapturing them. Whilst in Samo's case evidence is given as to how the court came by the evidence of former slavetraders and how Biggs persuaded some of them to testify and thereby 'atone' their guilt, ${ }^{69}$ in the account of Peters's case there is no information as to how the African witnesses came into contact with the court and the legal process. ${ }^{70} \mathrm{In}$ Peter's case it is the very absence of this trope that contributes to the erasure by the trial of Africans in redemption/emancipation, notwithstanding their extensive testimony in the courtroom. This is consistent with the logic of the 'savage-victim-savior' metaphor mentioned above.

Contemporary war crimes trials exhibit many similarities to the adjudicative framework adopted in Samo's case. There is a striking similarity between the optimism displayed by many contemporary international criminal lawyers in the transformative potential of the law and the claim that the slave-trading trials marked the first stage of emancipation. ${ }^{71}$ Typically, war crimes trials are show trials in so far as they direct their didactic gaze beyond the courtroom, ${ }^{72}$ and look to the future as much as to the past. ${ }^{73}$ Compared to other transitional justice mechanisms, such as truth commissions, contemporary international criminal hearings adopt a more retributive approach to the accused, allowing little space for amnesties. ${ }^{74}$ Despite this, international criminal hearings are permeated with ideas about individual and collective redemption. This can be seen in the claim, which is all too often made, that testifying is curative ${ }^{75}$ and avoids revenge. ${ }^{76}$

\footnotetext{
68 The Trials of the Slave Traders, 41.

69 ibid., 23.

70 This is a narrative framework that left little room for the participation — let alone agency — of Africans in processes of redemption, and for the replacement of stories of suffering with stories of resistance exemplified by the act of running away.

71 Biggs claimed, "This day will live in history, that will record this trial as the ground-work of that "universal emancipation" which it appears to be the will of the Almighty to spread, in process of time, throughout the world' (Trial of the Slave Traders, 27).

72 Hannah Arendt, Eichmann in Jerusalem: A Report on the Banality of Evil (London: Penguin Books, 1994); David Hirsh, Law Against Genocide: Cosmopolitan Trials (London: Glasshouse Press, 2003); Mark Osiel, Mass Atrocity, Collective Memory and the Law (New Jersey: Transaction Publishers, 2000); Simpson, 'Didactic and Dissident Histories', 804.

73 See, for example, Dembour and Haslam; Ruti Teitel, Transitional Justice (Oxford University Press, 2000). 74 See, for example, Diane Orentlicher, 'Settling Accounts: The Duty to Prosecute Human Rights Violations of a Prior Regime', Yale Law Journal 100 (1991): 2537-615.

75 See further, for example, Osiel, 273.

76 This approach also operated to defer, that is to control vengeance in Samo's case. Thorpe claimed: “'There is a God, all nature cries aloud," that marks the movements of this world, and brings us to account; when you are summoned before that great tribunal for judgment, and those unfortunate Africans, whom you branded on the thigh with burning implements of torture, shall arise in evidence against you, what can you expect from the seat of Supreme Justice?' (The Trials of the Slave Traders, 34).
} 
Whilst this framing dominates much of the literature, it is problematic. First, international criminal hearings have revealed a significant dislocation between the reality and promise of healing, for the courtroom is not a therapeutic forum - at least not for all. Stories of redemption have been shown all too often to instrumentalise survivors for the sake of the international criminal process. ${ }^{77}$ Although better practice and legal innovations can go some way towards mitigating some of the negative aspects of courtroom experiences, ${ }^{78}$ the redemptive framing of survivor testimony all too often instrumentalises victims in the service of a broader political project. This may include the construction of a political or international community ${ }^{79}$ and the expression of political contrition' ${ }^{80}$ Thus, redemption at the individual level is expected to contribute to redemption at a broader societal level. Notably, those who are 'saved'81 by participating in international criminal hearings rarely have a role in determining the broader agenda to which their participation avowedly contributes. In Samo's case this logic of redemption operated to buttress Britain's extra-territorial rights on the coast ${ }^{82}$ and to minimise the role of Africans in their own emancipation. Bringing slavery and abolition back into the picture of international criminal law, shows how this redemptive trope was driven less by a curative imperative than by an imperial project.

\section{Conclusion}

As 'the point in the constellation from which all legal discussion of war crimes trials proceeds or reverts', histories of international criminal law typically point to the Nuremberg and Tokyo trials as foundational. ${ }^{83}$ And yet, particular narrative framings of international criminal law have a longer trajectory than the

\footnotetext{
77 Dembour and Haslam.

78 For example, the establishment of victim participation at the International Criminal Court, widely seen as one response to the failure of the United Nations Tribunals for Yugoslavia and Rwanda to make adequate provision for the involvement of survivors in legal proceedings (Claude Jorda and Jérôme de Hemptinne, 'The Status and Role of The Victim', in Cassese, Gaeta and Jones, 1387-419).

79 On the appropriation of women's stories of sexual violence for the sake of 'post-conflict national identity' see Katherine M. Franke, 'Gendered Subjects of Transitional Justice', Columbia Journal of Gender and Law 15 (2006): 823. For Steinitz it is the international community which is the real subject of transition in the Milosevic trial (Maya Steinitz, 'The Milošević Trial Live!', Journal of International Criminal Justice 3 (2005): 107).

80 In the case of the establishment of the United Nations Security Council's International Criminal Tribunal for Rwanda see Ralph Zacklin, 'The Failings of Ad Hoc International Tribunals', Journal of International Criminal Justice 2 (2004): 542.

81 This language is taken from Anne Orford who writes of the challenge of how to respond to the 'victim who refused to be saved, the subject who will not speak her suffering in the time and place and languages offered to her by the mechanisms of transitional justice'. This indicates the ongoing rhetoric of saving in international criminal law (Anne Orford, 'Commissioning the Truth', Columbia Journal of Gender and Law 15 (2006), 883).

82 Letter from Thorpe to Governor Maxwell quoted in African Institution, Special Report, 101-02.

83 McGoldrick, 9-46.
} 
mid-twentieth century. This chapter does not trace an unbroken historical path. It does, however, suggest striking similarities between the narratives running through some of the first trials under the British Slave Trade Felony Act and contemporary international criminal hearings. In Samo's case, the deployment of redemption supported an imperial mission - inside and outside the courtroom. The implication of redemption in a colonial project challenges us to reflect upon the origins and use of narratives of redemption today. Admittedly, narratives of imperialism and colonialism in international criminal law play out differently in the contemporary context. ${ }^{84}$ However, Samo's case shows how this redemptive trope was tied up with a imperial project to which a politicised discourse of sin and redemption lent weight.

\section{Acknowledgments}

My thanks go to Kate Bedford, Rod Edmunds, Toni Williams and to the anonymous reviewer for their helpful comments.

84 As epitomised, for example, by the controversy surrounding the International Criminal Court's focus to date on the global south. See further Mahmood Mamdani, Saviours And Survivors: Darfur, Politics and the War On Terror (London: Verso, 2009). 